\title{
Shoot Production and Biomass Transfer of Big Sacaton [Sporobolus wrightii]
}

JERRY R. COX

\begin{abstract}
The annual pattern of above-ground live biomass, recent dead standing biomass, old dead standing biomass, and standing crop of big sacaton (Sporobolus wrightii Monro) grassland community in semiarid Arizona was studied over a 3-year period. Live biomass was produced throughout the year but peak production, over the 3 years, was in August. Peak biomass production was $296 \mathrm{~g} \mathrm{~m}^{-2}$ in 1 wet summer and averaged $133 \mathrm{~g} \mathrm{~m}^{-2}$ over 2 dry summers. Recent dead standing biomass was greatest in spring and least in summer, over the 3 years. Transfer of recent dead standing biomass to old dead standing biomass was precipitation and temperature dependent. Old dead standing biomass was greatest in summer, least in winter, and was primarily composed of dead seed stalks. Livestock management of big sacaton grasslands should possibly be distinct from adjacent upland areas.
\end{abstract}

Big sacaton (Sporobolus wrightii Monro) is a robust perennial warm-season bunchgrass that begins growth in early spring and usually produces a limited amount of green herbage in winter (Haferkamp 1982). The species grows on low alluvial flats and flood plains (Wooten and Standley 1912). It usually is excluded from alkaline and saline playas and lowlands dominated by alkali sacaton [Sporobolus airoides (Torr.) Torr.]. Big sacaton is distributed from southeastern Arizona to central Texas and

Author is range scientist, Arid Land Ecosystems Improvement, USDA, Agricultural Research Service, 2000 East Allen Road, Tucson, Ariz. 85719.

Appreciation is extended to R.M. Madrigal and B.B. Buck for field assistance; Drs. H.L. Morton and T.N. Johnsen, Jr., for technical assistance; the Donaldson family at the Empire Range for their cooperation; and ANAMAX Mining Company for permission to use their land.

Manuscript received August 17, 1983. south into the northern Mexican Frontier States; however, stand development is greatest in southeastern Arizona (Kearney and Peebles 1960).

Dense stands of big sacaton formerly dominated alluvial flats and bottomlands along the Santa Cruz and San Pedro Rivers in Southeastern Arizona and supported more than a million cattle in 1890 (Humphrey 1958). Big sacaton bottoms have been, and continue to be burned and grazed (Bock and Bock 1978), plowed and sown to agricultural crops (Griffiths 1901), channelized to provide irrigation water and drainage (Cooke and Reeves 1976), and covered with houses and asphalt (Renard et al. 1983). Today the species occupies less than 5\% of its original area (Humphrey 1960). Big sacaton stands were usually associated with perennial, surface water and new growth was readily consumed by livestock in spring when upland grasses were dormant (Thornber 1910). Dead standing big sacaton biomass is coarse and stands have been burned or mowed in either late fall, winter, or early spring for at least the past 100 years (Tharnber 1910, Humphrey 1970).

The animal-carrying capacity of semiarid grazing lands is dependent on net primary production and the amount of plant biomass which is available to be converted into animal biomass. Previous investigators have been interested in big sacaton production after natural and man-caused fires (Humphrey 1960, Bock and Bock 1978, Gavin 1982). However, net primary production rates under nonburned conditions have not been measured. The first step in a program to evaluate carrying capacity should be to quantify the annual accumulation and decomposition characteristics of live biomass and standing litter in big sacaton grassland communities. 
This paper reports on studies in which the above-ground live biomass production, recent dead standing biomass, and old dead standing biomass were examined over 3 years. The relative differences in yield accumulation and decomposition in response to climate were also studied.

\section{Study Area}

A study site representative of the big sacaton grassland ecosystem was located near the town of Sonoita in southeastern Arizona $\left(31^{\circ} 47^{\prime} \mathrm{N}\right.$ latitude, $110^{\circ} 37^{\prime}$ longitude) at an elevation of $1,370 \mathrm{~m}$. Soils were recent alluvium, weathered from mixed rocks, moderately alkaline, slightly calcareous and greater than $2 \mathrm{~m}$ in depth. The soil has been classified as Pima silty clay loam, sandy loam subsoil, thermic Typic Haplustoll (Richardson et al. 1979). The site was in a flood plain and slope was 1 to $2 \%$.

Vegetation was dominated by big sacaton. Other perennial grasses, which occurred infrequently, were alkali sacaton, blue grama (Bouteloua gracilis (Willd. ex H.B.K.) Lag. ex Griffiths), and vine mesquite (Panicum obtusum H.B.K.). Perennial trees were mesquite [Prosopsis juliflora (SW.) DC.], cottonwood (Populus deltoides Bartr. ex Marsh.) and walnut [Juglan major (Torr.) Heller]. Tree heights varied from 6 to $12 \mathrm{~m}$ along the riparian channel. The study site was $50 \mathrm{~m}$ from the channel and there were several large mesquite trees; either within or in close proximity to the site. Total annual precipitation in the area has varied from 175 to $450 \mathrm{~mm}$ in the past 50 years (Sellers and Hill 1974). Approximately $60 \%$ of the annual precipitation comes in summer (JulySeptember) when daily air temperatures are above $30^{\circ} \mathrm{C} ; 40 \%$ comes in winter (December-February) when night-time air temperatures are frequently below $0^{\circ} \mathrm{C}$. Fall (October-November) and spring (March-June) are cool, dry and windy.

\section{Methods}

The site was fenced to exclude livestock and was approximately 2 ha in area. Nine, $15 \times 15 \mathrm{~m}$ plots were established in a randomized block design with 3 replications. Three plots were randomly selected for sampling at 6-week intervals between 6 March 1980 and 6 February 1981 . Three additional plots were selected and sampled between 6 March 1981 and 6 February 1982 . The remaining 3 plots were sampled between 6 March 1982 and 6 February 1983.

Twenty $0.3 \times 2.9 \mathrm{~m}$ quadrats were located randomly within each plot at each sampling date; no quadrat location was resampled at any other time during the course of the experiment. Big sacaton plants in quadrats $1,5,10$, and 15 were harvested at the soil surface and hand separated into live biomass (green), recent dead standing biomass (yellow), and old dead standing biomass (gray) components. Each component was weighed in the field and a modified weight-estimate technique used to estimate biomass in the remaining quadrats (Pechanec and Pickford 1937). Harvested samples were dried in a forced draft oven at $40^{\circ} \mathrm{C}$ for $48 \mathrm{hr}$. Dry weights of live biomass, recent dead standing biomass, and old dead standing biomass were expressed in $\mathrm{g} \mathrm{m}^{-2}$. Regression techniques were used to correlate actual dry weights with estimated field wet weights (Campbell and Cassady 1949).

Standing crop was determined by adding live biomass, recent dead standing biomass, and old dead standing biomass components at each date. Such summations at 6-week intervals provide a conservative estimate of total standing crop because materials produced and broken-down between sampling dates are not included (Singh et al. 1975, Sims and Singh 1978). Annual net primary production (ANP) is normally calculated as the sum of the maximum live weights of individual species (Odum 1960). The contribution of other forbs, grasses and shrubs in this ecosystem was less than $1 \%$ at a sampling date, therefore, ANP is equated to peak standing crop.

Daily precipitation, maximum and minimum air temperature and wind speed were obtained at the site with a MRI Recording
Weather Instrument ${ }^{1}$. Daily values of precipitation and wind speed were accumulated for the 6 weeks prior to sampling. Daytime and night-time temperature extremes were summed over the 6 weeks and divided by total days to obtain a daily average.

Experimental design was a randomized block with 3 replications. Different plots were sampled in each of the 3 years. Live biomass, recent dead standing biomass and old dead standing biomass components, and standing crop were compared at the same date between years by analysis of variance. When $F$ values were significant ( $P \leq 0.05$ ) a Duncan's new multiple range test was used to separate means (Steel and Torrie 1960).

\section{Results}

\section{Above-ground Live Production}

Live biomass production showed a pronounced seasonal pattern (Table 1). Big sacaton above-ground live production peaked in either August or October and averaged 163 to $197 \mathrm{~g} \mathrm{~m}^{-2}$ over the 3 years. Corresponding values for winter and early spring (DecemberMarch) averaged 17 to $29 \mathrm{~g} \mathrm{~m}^{-2}$.

Live biomass production between years was different $(P \leq 0.05)$ only during August and October (Table 1). Total precipitation over the 12-week summer growing season (10 July - 2 October) was $165 \mathrm{~mm}$ in $1980,228 \mathrm{~mm}$ in 1981 and $147 \mathrm{~m}$ in 1982. Average live biomass produced during the 12-week summer growing season was $153 \mathrm{~g} \mathrm{~m}^{-2}$ in $1980,273 \mathrm{~g} \mathrm{~m}^{-2}$ in 1981 , and $114 \mathrm{~g} \mathrm{~m}^{-2}$ in 1982 . Precipitation was $11 \%$ greater and peak live biomass was $25 \%$ greater in 1980 as compared to 1982 , while precipitation was $35 \%$ greater and peak live biomass was $58 \%$ greater in 1981 as compared to 1982 . TThe mention of a commercial product is for the reader's convenience and does not
imply endorsement by the USDA, Agricultural Research Service.
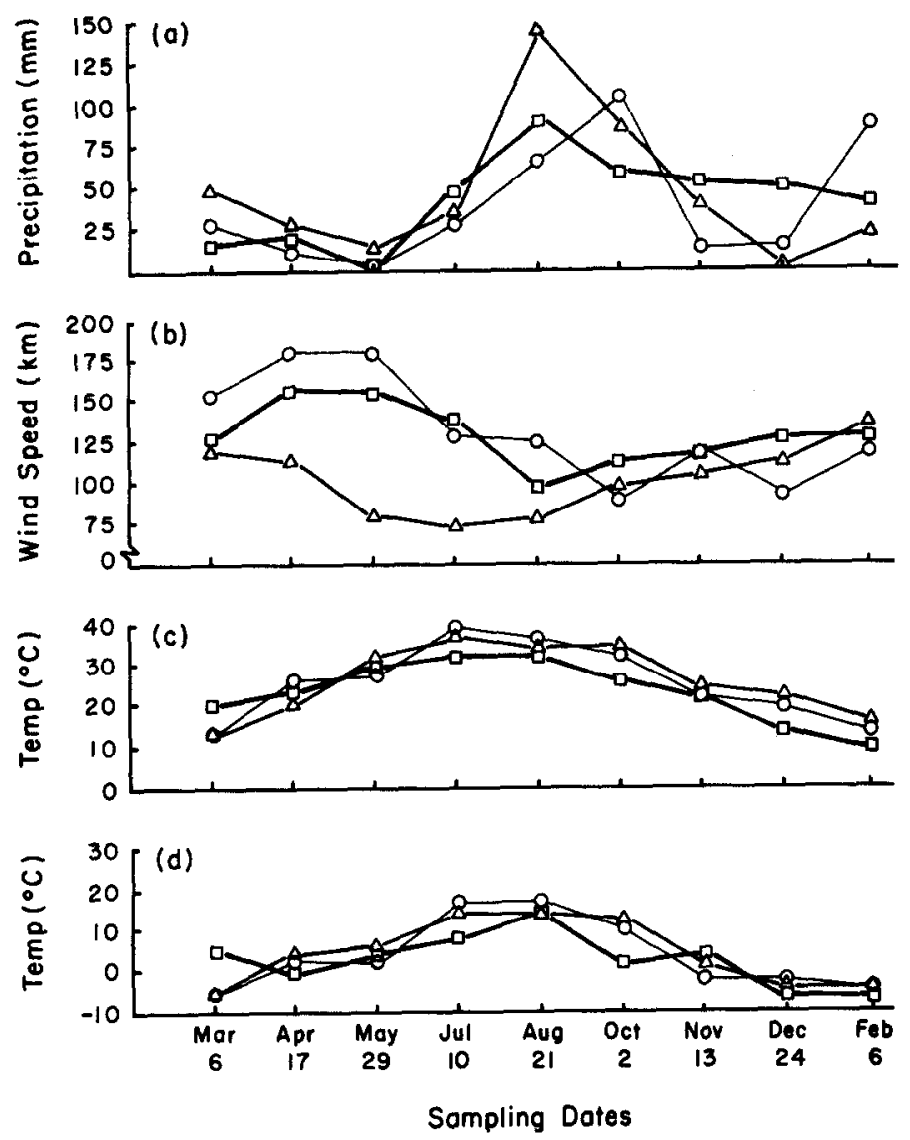

Fig. 1. Cumulative precipitation (a) wind speed (b), mean day-time (c), and. night-time (d) temperatures during the three years at a big sacaton' grassland site in southeastern Arizona. Sampling years were from 6 : March 1980 - 6 February 1981 (0); 6 March 1981 - February $1982(\Delta) ;$ and 6 March 1982 - 6 February 1983 (口). 
Table 1. Quantities ( $\mathrm{g} \mathrm{m}^{-2}$ ) of live, recent dead standing, old dead standing and standing crop of big sacaton (Sporobolus wrightï Monro.) sampled over three years in southeastern Arizona.

Sampling Dates'

\begin{tabular}{|c|c|c|c|c|c|c|c|c|c|c|}
\hline $\begin{array}{l}\text { Above-ground biomass } \\
\text { components }\end{array}$ & $\begin{array}{l}\text { Sampling } \\
\text { year }\end{array}$ & $\begin{array}{c}\text { March } \\
6\end{array}$ & $\begin{array}{c}\text { April } \\
17\end{array}$ & $\begin{array}{c}\text { May } \\
29\end{array}$ & $\begin{array}{c}\text { July } \\
10\end{array}$ & $\begin{array}{c}\text { August } \\
21\end{array}$ & $\begin{array}{c}\text { October } \\
2\end{array}$ & $\begin{array}{c}\text { November } \\
13\end{array}$ & $\begin{array}{c}\text { December } \\
24\end{array}$ & $\begin{array}{c}\text { February } \\
6\end{array}$ \\
\hline Live & $\begin{array}{l}1980-81 \\
1981-82 \\
1982-83\end{array}$ & $\begin{array}{r}7 \\
10 \\
33\end{array}$ & $\begin{array}{l}64 \\
51 \\
54\end{array}$ & $\begin{array}{l}96 \\
69 \\
42\end{array}$ & $\begin{array}{l}74 \\
87 \\
71\end{array}$ & $\begin{array}{l}158^{b} \\
326^{a} \\
108^{b}\end{array}$ & $\begin{array}{l}148^{b} \\
221^{a} \\
121^{b}\end{array}$ & $\begin{array}{l}35 \\
82 \\
30\end{array}$ & $\begin{array}{r}7 \\
52 \\
27\end{array}$ & $\begin{array}{l}19 \\
21 \\
20\end{array}$ \\
\hline Recent dead standing & $\begin{array}{l}1980-81 \\
1981-82 \\
1982-83\end{array}$ & $\begin{array}{r}169^{a} \\
90^{b} \\
199^{a}\end{array}$ & $\begin{array}{r}135^{a} \\
88^{b} \\
147^{a}\end{array}$ & $\begin{array}{l}128^{\mathrm{b}} \\
101^{\mathrm{b}} \\
167^{\mathrm{a}}\end{array}$ & $\begin{array}{r}136^{\star} \\
36^{b} \\
116^{\star}\end{array}$ & $\begin{array}{l}30 \\
10 \\
35\end{array}$ & $\begin{array}{l}72 \\
59 \\
21\end{array}$ & $\begin{array}{r}105^{b} \\
179^{a} \\
75^{b}\end{array}$ & $\begin{array}{c}136^{\mathrm{ab}} \\
162^{\mathrm{a}} \\
86^{\mathrm{c}}\end{array}$ & $\begin{array}{r}66^{b} \\
161^{a} \\
60^{b}\end{array}$ \\
\hline Old dead standing & $\begin{array}{r}1980-81 \\
1981-82 \\
198283\end{array}$ & $\begin{array}{l}202^{a} \\
125^{b} \\
212^{a}\end{array}$ & $\begin{array}{r}190^{a} \\
86^{b} \\
182^{\circ}\end{array}$ & $\begin{array}{r}189^{a} \\
97^{b} \\
224^{a}\end{array}$ & $\begin{array}{l}156^{a} \\
108^{b} \\
177^{a}\end{array}$ & $\begin{array}{l}232^{a} \\
102^{b} \\
245^{a}\end{array}$ & $\begin{array}{l}200^{a} \\
117^{b} \\
113^{b}\end{array}$ & $\begin{array}{r}144^{\mathrm{a}} \\
75^{\mathrm{b}} \\
148^{\mathrm{a}}\end{array}$ & $\begin{array}{r}78^{b} \\
112^{b} \\
166^{a}\end{array}$ & $\begin{array}{l}103 \\
167 \\
143\end{array}$ \\
\hline Standing crop & $\begin{array}{l}1980-81 \\
1981-82 \\
1982-83\end{array}$ & $\begin{array}{l}378^{a} \\
225^{b} \\
444^{a}\end{array}$ & $\begin{array}{l}389^{a} \\
225^{b} \\
383^{\mathrm{a}}\end{array}$ & $\begin{array}{l}413^{a} \\
267^{b} \\
433^{n}\end{array}$ & $\begin{array}{l}366^{\star} \\
231^{b} \\
364^{\star}\end{array}$ & $\begin{array}{l}420 \\
438 \\
388\end{array}$ & $\begin{array}{l}420^{a} \\
397^{a} \\
255^{b}\end{array}$ & $\begin{array}{l}284^{a b} \\
336^{a} \\
253^{b}\end{array}$ & $\begin{array}{c}221^{\mathrm{b}} \\
326^{\mathrm{a}} \\
279^{\mathrm{ab}}\end{array}$ & $\begin{array}{l}188^{b} \\
349^{a} \\
223^{b}\end{array}$ \\
\hline
\end{tabular}

IMeans in the same column followed by different superscripts within components are significantly different ( $P \leq 0.05$ ).

Live biomass production was similar for the November to July sampling dates over the 3 years (Table 1). Although the amount and distribution of precipitation in fall, winter and spring differed among years, there were no significant differences in live production because temperatures were less than optimum for plant growth (Fig. 1).

\section{Above-ground Recent Dead Standing Biomass}

Recent dead accumulations peaked in March, in 2 of 3 years, and averaged $153 \mathrm{~g} \mathrm{~m}^{-2}$ over the 3 years (Table 1). Corresponding values in August averaged $25 \mathrm{~g} \mathrm{~m}^{-2}$. Peak live biomass production decreased as precipitation and air temperature decreased (Fig. 1), and recent dead biomass increased in fall and winter. Recent dead biomass accumulations generally increased through fall and winter, gradually increased or decreased in spring, and rapidly declined during the summer growing season.

Recent dead accumulations and transfer to old dead were different $(P \leq 0.05)$ among years at all November to July sampling dates and similar when live biomass production peaked (Table 1). Recent dead accumulations in fall, winter, and spring were highly variable and the rate of transfer to old dead biomass was dependent upon the presence or absence of precipitation and cold air temperatures (Fig. 1). The rate of transfer was more uniform in summer due to the amount and distribution of precipitation and high air temperatures.

\section{Above-ground Old Dead Standing Biomass}

Old dead biomass accumulations peaked in either March or August and varied frm 180 to $193 \mathrm{~g} \mathrm{~m}^{-2}$ over the 3 years (Table 1). Old dead generally decreased in fall and winter, and gradually increased or decreased in spring and summer.

Old dead accumulations were greater $(P \leq 0.05)$ on March to August sampling dates in 1980 and 1982 as compared to the same dates in 1981 (Table 1). Spring and summer precipitation was greater than 50\% above average in 1981 and termite (Gnathamitermes perplexus) colonies removed the old standing dead seed stalks. Big sacaton seed stalks are high in lignin (Gavin 1982) and may persist for 3 or more years.

\section{Total Standing Crop}

Standing crop was highly variable between years and sampling dates (Table 1). Generally, standing crop was greatest in spring and summer and least in fall and winter. Peak standing crop, over the 3 years, occurred in August and averaged $415 \mathrm{~g} \mathrm{~m}^{-2}$.

\section{Discussion}

Gavin (1982) measured big sacaton live and total above-ground standing biomass production in west Texas $\left(30^{\circ} 05^{\prime}\right.$ latitude, $103^{\circ}$ 75' longitude) in 1978. Soils, slopes, air temperature, precipitation, and elevation are similar to those of the Arizona site, but the sites are separated by $700 \mathrm{~km}$. Peak live biomass production occurred in late August, at both sites, and was $266 \mathrm{~g} \mathrm{~m}^{-2}$ in Texas as compared to the 3 year mean of $197 \mathrm{gm}^{-2}$, in Arizona.

Above-ground net primary production (ANP) or big sacaton peak standing crop was $434 \mathrm{~g} \mathrm{~m}^{-2}$ in Texas (Gavin 1982) and averaged $415 \mathrm{~g} \mathrm{~m}^{-2}$, over the 3 years, in Arizona. ANP of 10 North American ungrazed temperate grasslands averaged $236 \mathrm{~g} \mathrm{~m}^{-2}$ and ranged from 54 to $523 \mathrm{~g} \mathrm{~m}^{-2}$ (Sims and Singh 1978). Mean sacaton ANP was intermediate between the mid- and tall-grass prairies.

In the past big sacaton communities, in lowland areas, received additional moisture in the form of runoff from nearby uplands and flood water from more distant mountainous areas (Renard et al. 1983). These processes which supplied additional moisture have been greatly reduced due to the formation of gullies and channels which rapidly drain water at the Arizona and Texas (Gavin 1982) sites. It seems reasonable to assume that the production potential would be much greater if runoff was moved out of existing channels and widely dispersed over big sacaton communities.

A major problem associated with the cattle industry in semiarid regions subject to periodic drought is how best to relate annual stocking rates to live biomass production (Christie 1981). Because little live biomass is produced in response to cool-season moisture, it would appear that stocking rates should be adjusted to the available forage at the end of summer, since the major portion of the live biomass is produced in mid summer. However, at this time livestock prefer the less coarse upland grasses, even though big sacaton herbage is abundant and nutritious. One possible management option might be to exclude big sacaton communities from surrounding uplands with fencing.

\section{Literature Cited}

Bock, C.E., and J.H. Bock. 1978. Response of birds, small mammals, and vegetation to burning sacation grasslands in southeastern Arizona. J. Range Manage. 31:296-300.

Campbell, J.B. and J.T. Cassudy. 1949. Determining forage weight on Southern forest ranges. J. Range Manage. 2:30-32.

Christie, E.K. 1981. Biomass and nutrient dynamics in a $\mathrm{C}_{4}$ semiarid Australian grassland community. J. Applied Ecology 18:907-918.

Cooke, R.U., and R.W. Reeves. 1976. Arroyos and environmental change in the American southwest. Clarendon Press, Oxford. 
Gavin, T.M. 1982. The effects of prescribed fire on the production, utilization and nutritional values of sacaton in Brewster County, Texas. M.S. Thesis, Sul Ross State University, Alpine, Tex.

Grifiths, D. 1901. Range improvement in Arizona. USDA, Bureau of Plant Industry. Bull. 4.

Haferkamp, M.R. 1982. Defoliation impacts on quality and quantity of forage harvested from big sacaton (Sprobolus wrightii Monro). J. Range Manage. 35:26-31.

Humphrey, R.R. 1958. The desert grassland. Bot. Rev. 24:193-253. Humphrey, R.R. 1960. Arizona range grasses. Arizona Agr. Exp. Sta. Bull. 298.

Humphrey, R.R. 1970. Arizona range grasses. Univ. Arizona Press, Tucson.

Kearney, T.H., and R.H. Peebles. 1960. Arizona flora. Univ. California Press, Berkeley.

Odum, E.P. 1960. Organic production and turnover in old-field succession. Ecology, 41:34-49.

Pechanec, J.F., and G.D. Pickford. 1937. A weight estimate method for determination of range or pasture production. J. Amer. Soc. Agron. 29:894-904
Renard, K.G., J.R. Cox, and D.F. Post. 1983. Effects of soil erosion on crop productivity in the southwest. Proc. Symp. on Soil Erosion and Crop Productivity. ASA, CSSA, and SSSA, Denver, Colo.

Richardson, M.L., G.D. Clemmons, and J.C. Walker. 1979. Soil survey of Santa Cruz and parts of Cochise and Pima Counties, Arizona. National Cooperative Soil Survey, USDA, Soil Conserv. Serv., Forest Service and Arizona Agr. Exp. Sta. Washington, D.C.

Sellers, W.D., and Hill, R.H. 1974. Arizona climate (1931-1972). Univ. of Arizona Press, Tucson.

Sims, P.L. and J.S. Singh. 1978. The structure and function of ten North American grasslands. III. Net primary production, turnover and efficiencies of energy capture and water use. J. Ecology 66:573-597.

Singh, J.S., W.K. Lauenroth, and R.K. Steinhorst. 1975. Review and assessment of various techniques for estimating net aerial primary production in grasslands for harvest data. Bot. Rev. 41:181-232.

Steel, R.G.D., and J.H. Torrie. 1960. Principles and procedures of statistics. McGraw Hill, New York.

Thomber, J.J. 1910. The grazing ranges of Arizona. Arizona Agr. Exp. Sta. Bull. 65.

Wooten, E.O., and P.C. Standley. 1912. The grasses and grass-like plants of New Mexico. New Mexico Agr. Exp. Sta. Bull. 81. 